\title{
Ortopedi ve travmatoloji asistan eğitiminin geleceği: Bizi neler bekliyor?
}

\section{The future of orthopedic and traumatology resident education: What awaits us?}

\author{
Irfan Esenkaya \\ İstanbul Medeniyet Üniversitesi, Tıp Fakültesi, S.B. Göztepe Eğitim ve Araştırma Hastanesi, \\ Ortopedi ve Travmatoloji Anabilim Dalı, İstanbul
}

\begin{abstract}
Tıpta uzmanlık eğitimi, üniversite veya Bakanlığa bağlı eğitim hastanelerinde yapılmaktadır. Esas olarak bu hastanelerde "Tıpta ve Diş Hekimliğinde Uzmanlık Eğitimi Yönetmeliği” usullerine göre uzmanlık ve yan dal eğitimleri verilmektedir. Tıpta Uzmanlık Kurulunun (TUK), tıpta uzmanlık eğitimiyle ilgili çeşitli ölçütlerin belirlenmesi, değerlendirilmesi ve takibinde önemli görev ve yetkileri vardır. Uzmanlık eğitimi çekirdek müfredatı ise Tıpta Uzmanlık Kurulu Müfredat Oluşturma ve Standart Belirleme Sistemi'ni (TUKMOS) oluşturan komisyonlar tarafından hazırlanmaktadır. Ortopedi ve travmatoloji uzmanlık eğitimine ait çekirdek müfredatı ise henüz sonlandırılmamıştır. Müfredatın oluşturularak üniversite ve Sağlık Bakanlığına bağlı eğitim hastanelerinde eşit özelliklerde uygulanması gerekli standardın yakalanması bakımından önemlidir.
\end{abstract}

Anahtar sözcülkler: ortopedi ve travmatoloji; tıpta uzmanlık eğitimi
Residency programs (residency training programs) (postgraduate education) are carried out in university hospitals or training hospitals belong to the Ministry of Health. Residency and subspecialty training programs are given according to the practice of "The Regulation of Residency Programs in Medicine and Dentistry". The Board of Residency Programs in Medicine has an important mission in defining, evaluation and pursuance of the criteria associated with the residency programs in medicine. The core curriculum of residency programs are prepared by the commissions that form the Curriculum Establishment and Defining Standards System in Board of Residency Programs in Medicine. The core curriculum related to orthopedics and traumatology is not finalized currently. The establishment of the curriculum and appliance of it in the university hospitals and training hospitals that belong to the Ministry of Health at equal terms carries utmost importance in seizing the necessary standards.

Key words: orthopedics and traumatology; residency training programs
U zmanlık eğitimin yapılacağı birim üniversite hastanesinde anabilim dalı / bilim dalı, Bakanlık hastanesinde ise klinik şeklinde yapılanmıştır. ${ }^{[1]} 2011$ veri ve 2013 bilgilerine göre; 51 ilde devlet üniversitelerine bağlı toplam 56 (58) tıp fakültesi, üç ilde vakıf üniversitelerine bağlı toplam 15 tıp fakültesi, 18 ilde Sağlık Bakanlığına bağlı toplam 67 eğitim ve araştırma hastanesi bulunmaktadır. ${ }^{[2]} \mathrm{Bu}$ hastanelerde "Tıpta ve Diş Hekimliğinde Uzmanlık Eğitimi Yönetmeliği”" usullerine göre uzmanlık ve yan dal eğitimleri verilmektedir. ${ }^{[3]} 2013$ Mayıs ayında yapılan Uzmanlık Eğitimi Gelişsim Sınavı (UEGS) değerlendirmelerine göre, bu eğitim kurumlarında yaklaşı 816 ortopedi ve travmatoloji asistanı/uzmanlık öğrencisi bulunmaktadır. ${ }^{[4]}$
Konuya hakim olabilmek için ilgili mevzuatı bilmek gerektiğinden, anlatımda sırası ile; Tıpta ve Diş Hekimliğinde Uzmanlık Eğitimi Yönetmeliği ${ }^{[3]}$, uzmanlık eğitimi çekirdek müfredatları, ${ }^{[5,6]}$ tıpta uzmanlık kurulu (TUK) karar tutanakları, ${ }^{[1,7,8]}$ tıp dekanları konseyi kuruluş ve çalışma esasları yönergesine ${ }^{[9]}$ değinilerek ilgili mevzuatların günlük uygulamadaki örnekleri değerlendirme bölümünde ele alınmıştır.

\section{TIPTA VE Diş HEKIMLiĞiNDE UZMANLIK EĞiTiMi YÖNETMELiĞi}

Tıpta Uzmanlık Kurulu'nun internet sitesinde (WEB sayfasında) konuyla ilgili olarak eski mevzuat (19622009) ve yürürlükteki mevzuat (1928-2014) başlıkları

- İletişim adresi: Prof.Dr. İrfan Esenkaya, İstanbul Medeniyet Üniversitesi, Tıp Fakültesi, S.B. Göztepe Eğitim ve Araştırma Hastanesi, İstanbul Tel: 0216 - 5709100 e-posta: iesenkaya@hotmail.com

- Geliş tarihi: 30 Ağustos 2014 Kabul tarihi: 24 Ekim 2014 
altında çeşitli kanun, kanun hükmünde kararname, yönetmelik ve tüzükler vardır. ${ }^{[10]}$

26 Nisan 2014 tarihli 28983 sayılı resmi gazetede yayınlanan "Tıpta ve Diş Hekimliğinde Uzmanlık Eğitimi Yönetmeliği” yürürlükteki mevzuatların en yenisidir. ${ }^{[3]}$ Buna göre:

Madde 1. Yönetmeliğin amacını açıklamaktadır. Bu Yönetmeliğin amacı, "tıp ve diş hekimliği alanlarında uzmanlık eğitimi, uzmanlık belgelerinin verilmesi ve Tıpta Uzmanlık Kurulunun çalışma usul ve esaslarını düzenlemektir.”[3]

Madde 2. Yönetmeliğin dayanağını açıklamaktadır. Bu Yönetmelik, 11/4/1928 tarihli ve 1219 sayılı Tababet ve Şuabatı San'atlarının Tarzı İcrasına Dair Kanun ile 11/10/2011 tarihli ve 663 sayılı Sağlık Bakanlığı ve Bağlı Kuruluşlarının Teşkilat ve Görevleri Hakkında Kanun Hükmünde Kararnamenin 22'nci maddesine dayanılarak hazırlanmıştır. ${ }^{[3]}$

Madde 4 ve Madde 5. Madde 4, Tıpta Uzmanlık Kurulunun oluşumu ve çalışma esasları ile Madde 5, Kurulun görevlerinden bahsetmektedir. Madde 5'te; çekirdek eğitim müfredatının, buna göre ilgili uzmanlık alanının temel uygulama alanları ile temel görev ve yetkilerinin çerçevelerinin belirlenmesi ile takipleri; rotasyonların ve sürelerinin belirlenmesi; uzmanlık eğitim sürelerinin gerekirse $1 / 3$ oranında arttırılması; uzmanlık eğitimi bitirme sınav jürinin seçim ölçütlerinin belirlenmesi ve benzeri toplam 16 şıktan oluşan kurulun görevleri tanımlanmıştır. ${ }^{[3]}$

Madde 11. Uzmanlık öğrencisinin tanımlamasını yapmıştır:

1) Uzmanlık öğrencisi; kurumlarındaki kadro unvan ne olursa olsun, bu Yönetmelik ve ilgili mevzuat hükümleri çerçevesinde programlarda uzmanlık eğitimi gören, araştırma ve uygulama yapan kişilerdir.

2) Programlara yerleştirilen uzmanlık öğrencilerinin istihdam şekli, kurumlarının özel mevzuat hükümlerine tabidir.

3) Uzmanlık öğrencisi muayenehane açamaz, uzmanlık eğitiminin gerektirdiği durumlar dışında aylıklı veya aylıksız hiçbir işte çalışamaz. Bu şekilde çalıştığı tespit edilen uzmanlık öğrencisinin ilgili eğitim kurumunca ilişiği kesilir.

4) Uzmanlık öğrencileri, uzmanlık eğitimi uygulamasından sayılmayan işlerde görevlendirilemez.

5) Uzmanlık öğrencilerinin nöbet uygulaması üç günde birden daha sık olmayacak şekilde düzenlenir.
6) Uzmanlık öğrencisinin programlarda, kurul tarafından belirlenmiş müfredat ve standartlarda verilmesinin sağlanmasını isteme hakkı vardır. Nöbet, çalışma ve eğitim odaları gibi eğitsel ve sosyal gereksinimleri karşılayan alt yapı ve diğer standartlar kurumca sağlanır.

7) Uzmanlık öğrencisi, programda bulunan bütün eğiticilerin gözetim ve denetiminde araştırma ve eğitim çalışmalarında ve sağlık hizmeti sunumunda görev alır, deontolojik ve etik kurallara uyar. ${ }^{[3]}$

Madde 17. Uzmanlık eğitiminin takibi ve değerlendirilmesiyle ilgilidir. Uzmanlık eğitiminin takibi ve değerlendirilmesi Bakanlık tarafından elektronik ağ ortamı kullanılarak kurulan "Uzmanlık Eğitimi Takip Sistemi (UETS)" çerçevesinde yapılır. UETS; çekirdek eğitim müfredatı, genişletilmiş eğitim müfredatı, uzmanlık eğitimi karnesi, program yöneticisi kanaati, tez çalışmasının takibi, uzmanlık öğrencisi kanaati, uzmanlık eğitimi süre takibi, denetim formu ve uzmanlık eğitimi yeterlilik sistemi unsurlarından oluşur. ${ }^{[3]}$

Madde 18. Uzmanlık ana ve yan dalları ile eğitim süreleri ve rotasyonlarla ilgilidir. ${ }^{[3]}$

Madde 19. Uzmanlık öğrencilerinin uzmanlık tezi ve değerlendirilmesiyle ilgilidir. Uzmanlık öğrencisinin ana dalda uzmanlık eğitimi bitirme sınavına girebilmesi için tez hazırlaması zorunludur. Bu Madde'nin ilk üç şıkkı “Uzmanlık eğitimi süresinin ilk yarısı içinde uzmanlık öğrencisine bir tez konusu ve tez danışmanı belirlenir. Tez, en geç uzmanlık eğitimi süresinin bitiminden üç ay öncesinde asıl üyelerinden en az biri kurum dışından belirlenen ve en az üç asıl iki yedek üyeden oluşan jüriye sunulmak üzere program yöneticisine teslim edilir.” şeklindedir. ${ }^{[3]}$

\section{UZMANLIK EĞiTIMI ÇEKIRDEK MÜFREDATLARI}

2008 yılında (v.0.5), ortopedi ve travmatoloji uzmanlık dalının da içinde bulunduğu 41 uzmanlık dalı için uzmanlık eğitimi müfredat çalışmaları için başlatılmıştır. 2011 (v.1.0) ve 2013 (v.2.0) yıllarında 96'şar uzmanlık dalı için taslak müfredat çalışmaları yapılmış olup 2014 Ağustos tarihi itibarı ile 18 uzmanlık dalının çekirdek müfredatı kabul edilmiştir. Ortopedi ve travmatoloji uzmanlık dalının uzmanlık eğitimi müfredat çalışması henüz son şeklini almamıştır. ${ }^{[5,6]}$

Ortopedi ve travmatoloji uzmanlık dalının 04.06.2013 tarihine ait 24 sayfadan oluşan taslak müfredat çalışmaları içerisinde (v.2.0); müfredat, temel 
yetkinlikler, öğrenme ve öğretme yöntemleri, eğitim kaynakları, ölçme ve değerlendirmeye yer verilmiştir. ${ }^{[5,6]}$

Henüz tamamlanmamış olan bu taslak çekirdek müfredat (v.2.0) içerisinde:

Müfredatın amacı; "Bu dalda yetişmekte olan uzmanlık öğrencilerini kas-iskelet sistemi hastalıkları ve travmatolojisi açısından tanı ve tedavide yetkin kılmak, onları tıp ahlakı yönüyle iyi bir uygulayıcı haline getirmektir. Genç meslektaşlarımıza mesleki yaşamında gerekli olacak bilgi, beceri ve tutumları kazanmaları ve geliştirmeleri için yardımcı olmaktır." şeklinde açıklanmıştır. ${ }^{[6]}$

Uzmanlık eğitim süreci olarak; "Ortopedi ve travmatoloji uzmanlık eğitiminin süresi beş yıldır. Bu süre içinde; a) Yetişkin ortopedisi alanında en az 12 ay, b) Erişkin travması alanında en az 12 ay, c) Pediatrik ortopedi ve travma alanında en az 12 ay ve d) Ortopedinin diğer alt alanlarında en az altı ay çalışmak zorunludur. Uzmanlık öğrencisinin bağlı olduğu eğitim programında bu koşullar sağlanamadığı taktirde başka bir eğitim kurumunda yeterli süre rotasyona gönderilmesi gereklidir." açıklamaları vardır. ${ }^{[6]}$

Temel yetkinlik bölümünde yedi temel yetkinlik alanından oluşan TUKMOS'un yeterlilik üçgeni oluşturulmuştur. Bu üçgenin tabanını ekip üyesi, yönetici, sağlık koruyucusu; ortasını iletişim kuran, değer ve sorumluluk sahibi, öğrenen ve öğreten gibi altı özellik oluştururken üçgenin tepesine hizmet sunucusu özelliği yerleştirilmiştir. ${ }^{[6]}$

Ilerleyen bölümlerde klinik yetkinlikler ile öğrenme ve öğretme yöntemlerine değinilmiştir. ${ }^{6]}$

Eğitici standartları için; "Biri en az doçent olmak üzere ortopedi ve travmatoloji uzmanı olan üç eğitici olması gereklidir. Eğiticiler en az üç yıllık uzman olmalıdır. Eğiticiler bir eğitim kurumunda en az bir yıl uzman olarak çalışmış olmalıdır. Yatak sayısı 35'e kadar olan kliniklerde eğitici/asistan oranı en az $1 / 2$ olmalıdır. Yatak sayısı 35'ten fazla olan kliniklerde bu oran en az $1 / 3$ olmalıdır. Kurumda bir yıl içinde yapılan A, B, C grubu ameliyat sayısı araştırma görevlisi başına en az 100 adet olmalıdır." önerisi vardır. ${ }^{[6]}$

\section{TIPTA UZMANLIK KURULU KARAR TUTANAKLARI}

Tıpta uzmanlık kurulunun 23.06.2010 tarih ve 82 sayılı kararı rotasyonlarla ilgilidir: rotasyona gönderen ve rotasyona gönderilen uzmanlık alanı, asistanlık yılı ve rotasyon süresi/süreleri belirtilmiştir. Buna göre ortopedi ve travmatoloji uzmanlık dalı için; birinci sene Acil Tip ( 2 ay) ve Genel Cerrahi ( 1 ay), ikinci sene Anesteziyoloji ve Reanimasyon (2 ay) ve Fiziksel Tıp ve Rehabilitasyon (1 ay), üçüncü sene Kalp ve Damar
Cerrahisi ( 1 ay) ve Plastik, Rekonstrüktif ve Estetik Cerrahi ( 2 ay) dallarında rotasyon önerilmiştir. ${ }^{[7]}$

Tıpta uzmanlık kurulunun 5 Kasım 2013 tarihli 52 nolu toplantısında alınan 399 nolu kararda; Uzmanlık eğitimi vermek isteyen bir kurum, ilgili uzmanlık dalıyla ilişkili birden fazla birime sahip olabilmektedir (örneğin aynı üniversiteye ait birden fazla aynı adı taşıyan bilim dalı). Bir kurumda bir uzmanlık dalı ile ilişkili olabilecek birden fazla birim varken, ilave olarak o uzmanlık dalında verilecek eğitimde rol oynayabilecek ünite, laboratuvar, servis vb. isimler altında ve kurumun akademik ve hiyerarşik yapılanması kapsamında farklı birimlere bağlı farklı bileşenler de ayrıca mevcut olabilmektedir. Bu karara ve yukarıdaki açıklamalara göre; a) genel cerrahi, b) plastik, rekonstrüktif ve estetik cerrahi ve c) ortopedi ve travmatoloji ana dallarından en az ikisinin bulunması durumunda (üçüncüsü dışarıdan bir başka anabilim dalından / klinikten olabilir) el cerrahisi yan dal eğitimi verecek program protokolü oluşturulabilir. ${ }^{[1]}$

Tıpta uzmanlık kurulunun 20-21 Mayıs 2014 tarihli 57 nolu toplantısında alınan 479 nolu karar "Uzmanlık öğrencilerinin uzmanlık eğitimi çerçevesinde yapacağı uzmanlık tezi" ile ilgilidir. 7 maddeden oluşan bu kararda ilk 2 madde aşağıdaki şekildedir.

1) Uzmanlık öğrencisinin ana dalda uzmanlık eğitimi bitirme sınavına girebilmesi için tez hazırlaması zorunludur.

2) Uzmanlık eğitiminin ilk yarısı içinde; program yöneticisi tarafından uzmanlık öğrencisine ilgili dalda eğitici niteliğini haiz bir tez danışmanı tayin edilir ve tez danışmanı tarafından da uzmanlık öğrencisinin tez konusu belirlenir. Tez konusu ilgili akademik kurulca onaylanır. ${ }^{[8]}$

\section{TIP DEKANLARI KONSEYI KURULUŞ VE ÇALIŞMA ESASLARI YÖNERGESI}

TıpDEK'in amacı, ülkemizdeki tıp eğitiminin planlanması uygulanması ve değerlendirilmesi, tıp biliminin gelişmesi, bilimsel faaliyetler ve bunlarla ilişkili olarak sağlık hizmeti sunumu üzerinde görüş alışverişinde bulunmak, tıp eğitiminin etkin ve verimli bir biçimde yürütülmesini sağlamak üzere öneriler geliştirmek, bu önerilerin gerçekleştirilmesi yönünde projeler üretmek ve gerekli işlemleri yapmaktır. ${ }^{[9]}$

\section{ILGILI MEVZUAT DOĞRULTUSUNDA, DEĞERLENDIRME}

Tıpta Uzmanlık Kurulunun internet sitesinde (WEB sayfasında) eski mevzuat (1962-2009) ve yürürlük- 
teki mevzuat (1928-2014) başlıkları altında çeşitli kanun, kanun hükmünde kararname, yönetmelik ve tüzükler vardır. 1962 ve 1973 yıllarında "Tababet Uzmanlık Tüzüğü", 1974 yılında "Tababet Uzmanlık Yönetmeliği”, 2002 yılında "Tıpta Uzmanlık Tüzüğü”, 2007 yılında "Tıpta Uzmanlık Kurulunun Teşkil Olmasına Dair Kanun", 2009 yılında "Tıpta ve Diş Hekimliğinde Uzmanlık Eğitimi Yönetmeliği” ile 2007 yılında "Yan Dal Uzmanlık Sınavı Giriş Yönetmeliği" yürürlüğe girmiş, ancak daha sonra hazırlanan yeni mevzuatla yürürlükten kaldırılmışlardır. 04.11.1981 tarihli 2547 sayılı Yükseköğretim Kanunu yürürlükteki mevzuat içinde olsa da sonraki yıllarda pek çok değişiklik yapılmıştır. ${ }^{[10]} 26$ Nisan 2014 tarihli 28983 sayılı resmi gazetede yayınlanan "Tıpta ve Diş Hekimliğinde Uzmanlık Eğitimi Yönetmeliği” yürürlükteki mevzuatın en yenisidir. Madde 4 ve Madde 5, Tıpta Uzmanlık Kurulunun (TUK) oluşumu ve çalışma esasları ile görevlerinden bahsetmektedir. Madde 5, d-şıkkına göre "uzmanlık dallarının eğitim sürelerinin üçte bir oranına kadar arttırılabilmesi hakkında karar vermek" yetkisi vardır. ${ }^{[3]}$ Nitekim TUK'un 20.06.2014 tarihli 58 toplantı nolu $488^{\prime}$ inci karar tutanağında da ${ }^{[11]}$ olduğu gibi, Türk Anesteziyoloji ve Reanimasyon Derneğinin (TARD) dilekçelerindeki istemleri ${ }^{[12]}$ doğrultusunda eğitim süresinin dört yıldan beş yıla çıkartılmasını Anesteziyoloji ve Reanimasyon TUKMOS Komisyonuna önererek bu doğrultuda karar almışlardır. Buradan da anlaşılıyor $\mathrm{ki}$, ana dal ve yan dal uzmanlık dallarının eğitim süreleri zaman içerisinde değiştirilebilir.

2008 yılında başlatılan ortopedi ve travmatoloji uzmanlık dalı için uzmanlık eğitimi müfredat çalışmaları halen devam etmektedir. 2008, 2011 ve 2013 yıllarında yapılan hazırlık çalışmaları[ ${ }^{[5]}$ III. Dönem TUKMOS Komisyonu tarafından şekillendirilecektir.

Uzmanlık eğitim süresi içinde; a) Yetişkin ortopedisi alanında en az 12 ay, b) Erişkin travması alanında en az 12 ay, c) Pediatrik ortopedi ve travma alanında en az 12 ay ve d) Ortopedinin diğer alt alanlarında en az altı ay çalışmak zorunludur. Uzmanlık öğrencisinin bağlı olduğu eğitim programında bu koşullar sağlanamadığı taktirde başka bir eğitim kurumunda yeterli süre rotasyona gönderilmesi gereklidir."[6] Her anabilim dalında / klinikte yukarıda bahsedilen alt alanlarda eğitim verilemeyebilir. Bu eksiklik ileride belki birlikte kullanım protokolü içerisine dahil edilen ortak kullanımdaki hastanelerin uygulamaya sokulması ile çözülmeye çalışılacaktır. Halbuki eğitim verme özelliğinde olan anabilim dalına / kliniklere eğitim programında olması gereken alt alanlarda yeteneği/tecrübesi olan kişilerin alınması ile bu eksiklik giderilebilir. Önümüzdeki yıllarda birçok hastanenin ortak kullanım adı altında birbirine afiliye olmaları planlandı ise, uzmanlık eğitimi alan asistanın klinikler arasında dolaşması gündeme gelebilir. 2009-2011 arası çeşitli illerdeki 11 üniversite hastanesi Sağlık Bakanlığına bağlı devlet ya da eğitim ve araştırma hastaneleriyle ortak kullanıma geçmiştir. ${ }^{[13]}$

v.2.0. - 2013 yılına ait ortopedi ve travmatoloji uzmanlık eğitimi taslak çekirdek müfredatında temel yetkinlik bölümünde, yedi temel yetkinlik alanından oluşan “TUKMOS'un yeterlilik üçgeni” oluşturulmuştur. Bu üçgenin tabanını ekip üyesi, yönetici, sağlık koruyucusu; ortasını iletişim kuran, değer ve sorumluluk sahibi, öğrenen ve öğreten gibi altı özellik oluştururken üçgenin tepesine hizmet sunucusu özelliği yerleştirilmiştir. ${ }^{[6]}$ Bilindiği gibi uzmanlık eğitimi veren üniversite hastaneleri ile Bakanlık eğitim ve araştırma hastanelerinde hizmet ile eğitim iç içedir. Halbuki sağlık hizmeti sunucuları; birinci basamak sağlık kuruluşu ile ikinci ve üçüncü basamak sağılı kurumları olarak üçe ayrılmaktadır. Uzmanlık eğitimi yetiştirme görevi olan Sağlık Bakanlığına bağlı eğitim ve araştırma hastaneleri ile üniversite hastaneleri ile bu hastanelere bağlı sağlık uygulama ve araştırma merkezleri üçüncü basamak hastaneler olarak kabul edilmektedir. ${ }^{[14-16]}$ Ancak üçüncü basamak olması gereken, uzmanlık eğitimi verme ve uzman yetiştirme görevi olan Sağlık Bakanlığına bağı eğitim ve araştırma hastaneleri ile üniversite hastaneleri ile bu hastanelere bağlı sağlık uygulama ve araştırma merkezleri ikinci basamak devlet hastaneleri gibi çalışmaktadır. 2009-2011 arası çeşitli illerdeki 11 üniversite hastanesi Sağlık bakanlığına bağlı devlet ya da eğitim ve araştırma hastaneleriyle ortak kullanıma geçmiştir. Eğiticiler ve uzmanlık eğitimi alan asistanlar üzerindeki hizmet yükünün fazla olduğu bu tür protokoller eğitimi olumsuz olarak etkilemektedir. ${ }^{[13]}$ Eğitimi ikinci plana iten hizmet ağırlıklı bu tür uygulamalar, ortak kullanım adı altında önümüzdeki yıllarda daha da yaygınlaşabilir.

"Tıpta ve Diş Hekimliğinde Uzmanlık Eğitimi Yönetmeliği" nin Madde 17'si uzmanlık eğitiminin takibi ve değerlendirilmesiyle ilgilidir. Uzmanlık eğitimi karnesinin oluşturulması ve takibi önemlidir. [3] "Türk ortopedi ve Travmatoloji Eğitim Konseyi (TOTEK)'nin eğitim kliniklerine bir yaptırım talimatı iletememesi nedeniyle asistan karnesinin yaygın olarak kullanıma sokulamadığı” v.1.0. - 2011 yılına ait ortopedi ve travmatoloji uzmanlık eğitimi taslak çekirdek müfredat çalışmasında belirtilmiştir. ${ }^{[17]}$ TOTEK yine de asistan karnesiyle ilgili çalışmalarına devam etmiş, gerekli güncellemeleri yapmış ve eğitim veren tüm kliniklere gönderilmiştir. ${ }^{[18]}$ Yakın bir zaman önce, Sağlık Bakanlığına bağlı bazı eğitim hastanelerinde Kurumsal Eğitim Yönetimi ve Planlama Sistemi (KEYPS) adı altında, Tıpta Uzmanlık Bilişim Modülü olan elektronik kayıt ve takip sistemi uygulanmaya başlanmıştır. KEYPS'in; kurumun 
eşdeğerleri ile birlikte bir eğitim ağı içinde yer almasını sağladığı, müfredat geliştirmeye, eğitimin uygulanmasına, elektronik sınav yapmaya ve e-portfolyo oluşturmaya olanak tanıdığı ifade edilmiştir. Başlangıçta asistan kanaat notlarının temel yetkinlikler değerlendirilmesi başlı̆̆ı altında girileceği bu sistemde (360 derece değerlendirme başlığı altında) ileride geri bildirimler, sınavlar ve takipler ile asistan karnesi bu elektronik ortamda saklanabilecektir. ${ }^{[19]}$

Tıpta uzmanlık kurulunun 20-21 Mayıs 2014 tarihli 57 nolu toplantısında alınan 479 nolu karar "Uzmanlık öğrencilerinin uzmanlık eğitimi çerçevesinde yapacağı uzmanlık tezi” ile ilgilidir. 7 maddeden oluşan bu kararda ilk maddesi aşağıdaki şekildedir: Uzmanlık öğrencisinin ana dalda uzmanlık eğitimi bitirme sınavına girebilmesi için tez hazırlaması zorunludur. [8] Aynı şekilde "Tıpta ve Diş Hekimliğinde Uzmanlık Eğitimi Yönetmeliği”nin Madde 19'u da uzmanlık öğrencilerinin uzmanlık tezi ve değerlendirilmesiyle ilgilidir. ${ }^{[3]}$ Uzmanlık eğitimi bitirme sınavına girebilmesi için tez hazırlanması zorunlu iken İstanbul Medeniyet Üniversitesi tarafindan düzenlenen "Yeni YÖK Yasa Taslağı'nda Tıpta Uzmanlık Eğitimi Çalıştayı, Tıpta uzmanlıkta tez kaldırılsın mı?” konu başlıklı çalıştayda; tezli-tezsiz uzmanlık, uzmanlık ve tıpta doktora konuları yurtdışındaki örnekleriyle tartışıldı. ${ }^{20]}$ "Tez yapma zorunluluğu kaldırılırsa uzman olanlar akademik kariyer yapabilecekler mi? Tezli uzmanlık için ilave süre gerekecek midir? Tezsiz uzmanlık yapanlar akademik kariyer yapmak istediklerinde ne olacak?" sorularının cevaplanması gerektiği de ayrıca belirtildi. [2] "Uzmanlıkta tez gerekli mi? Uzmanlık/doktora bütünleşik eğitimi olabilir mi?” konularının tartışıldığı bir başka toplantıda; uzmanlık müfredatlarının hasta hizmetine yönelik olduğu, uzmanlık çekirdek eğitim programında hasta hizmetinin esas olduğu ve uzmanlık eğitiminin temelde akademisyen yetiştirmeyi hedeflemediği, uzmanlıkta tez olmaması ve öğretim üyesi olmanın belli yeterlilikleri gerektirmesi gerektiği gibi konular gündeme getirildi.[21] "Tıpta uzmanlık doktoraya eş midir?" konusu ileride sıkça gündeme gelebilir.

Tıpta uzmanlık kurulunun 5 Kasım 2013 tarihli 52 nolu toplantısında alınan 399 nolu kararda yan dal açılmasıyla ilgili protokollerden bahsedilmiştir. ${ }^{[1]}$ Genel cerrahi, plastik-rekonstrüktif ve estetik cerrahi ile ortopedi ve travmatoloji ana dalları nasıl el cerrahisi yan dalı eğitimini açabiliyorlarsa belki de ileride ortopedi ve travmatolojinin de içinde bulunduğu farklı ana dallar farklı yan dallar açabilecektir.

Üçüncü basamak olması gereken, uzmanlık eğitimi vererek uzmanlık öğrencisi yetiştirme görevi olan Sağlık Bakanlığına bağlı eğitim ve araştırma hastaneleri ile üniversite hastaneleri ile bu hastanelere bağlı sağlık uygulama ve araştırma merkezleri ${ }^{[14-16]}$ ikinci basamak devlet hastaneleri gibi çalışmaktadır. Uzmanlık eğitimi verdikleri için "eğitim hastanesi" olarak isimlendirilen bu hastanelerdeki asistan sayılarının giderek azaldığı bilinen bir gerçektir. 2012 yılı için tüm branşlardaki uzman hekim sayısı 64.768 olup, 2023 yılı için planlanan uzman hekim sayısı 118.050 olarak hesaplanmıştır. 11 yılda 53.282 uzman ihtiyacı söz konudur. Ortalama yıllık sisteme dahil olan uzman sayısı (ihtiyaç olan branşlarda) 4.500 civarındadır. Ortopedi ve travmatoloji için 2662 uzmanın çalıştığı ve 2023 yılı için 4000 uzman ihtiyacı olduğu belirtilmiştir. ${ }^{[2]}$ Rakam sabit kaldığı takdirde 11 yıl sonrası için 1338 ortopedi ve travmatoloji uzmanına ihtiyaç vardır. Ölümler ve emekliye ayrılanlar dışında değişen travma ve hastalık şekilleri nedenleriyle, projeksiyonu yapılan sayılar yeterli olmayacaktır. Ancak yine de Tıpta Uzmanlık Eğitimi Giriş Sınavı (TUS) sonrası kliniklere az sayıda asistan verilmektedir.

Tıpta uzmanlık eğitimi çağa uygun olarak teknolojik gelişmelerden yararlanmalıdır. Eğitimin içerisine: ileri teknoloji ürünü maket, manken ve sanal programlar, görüntüye dayalı simülatörler; aslına uygunluğu yüksek, girişimsel simülatörler; yüksek teknolojili interaktif hasta simülatörleri; sanal gerçeklik ve dokunmatik sistemler dahil edilmelidir. Bu amaçla ameliyat odası şeklinde laboratuvarlar ve multidisipliner tıbbi simulasyon merkezleri açılabilir. ${ }^{[22]}$

Avrupa Birliğinin üzerinde çalıştı̆̆ı, bilmek, görmek, yardımla uygulamak, yardımsız uygulamak ve bağımsız pratik yapabilme yeteneğinin kazanılmasından oluşan beş seviyeli beceri uygulaması temelli ortak müfredat çalışma ve uygulamasını ı23] bizler kendi eğitim hastanelerimiz için oluşturmalıyız. Bunun için de, gerek üniversite gerekse Bakanlığa bağlı eğitim hastanelerindeki tüm eğitim sorumlu ve görevlileri ilgili mevzuatları inceleyerek, son şeklini alacak III. Dönem TUKMOS içerisinde yer alacak uzmanlık eğitimi çekirdek müfredatı ile ilgili fikir oluşturmaları gerekmektedir.

Yukarıda açıklandığı gibi, Tıpta Uzmanlık Kurulunun internet sitesinde (WEB sayfasında) eski mevzuat (1962-2009) ve yürürlükteki mevzuat (1928-2014) başlıkları altında çeşitli kanun, kanun hükmünde kararname, yönetmelik ve tüzükler vardır. ${ }^{[10]}$ Bunlar zaman içerisinde değişikliğe uğramakta ya da eskilerini geçersiz bırakacak şekilde yenileri çıkmaktadır. "Ülkemizin başta tabip ve uzman tabip olmak üzere, sağlık insan gücü açığının karşılanması amacıyla, Sağlık bilimleri ve tıp alanında eğitim vermek üzere Türkiye Sağlık Bilimleri Üniversitesinin kurulması ve sağlık personeline, aile hekimliğine ve yükseköğretime ilişkin olarak uygulamada karşılaşılan bazı sorunların giderilmesine yönelik çeşitli düzenlemelerin yapılması" 
öngörülerek komisyondan geçen Kanun Tasarısı ${ }^{[24]}$ yasalaşır ve Türkiye Sağlık Bilimleri Üniversitesinin kurulursa, uzmanlık eğitiminin, eğitimi alan ve eğitimi veren bakımından alacağı şekli şimdiden görmemiz mümkün değildir. Belki de uygulamadaki mevzuatların çoğu tekrardan değişecektir.

\section{KAYNAKLAR}

1. Tıpta Uzmanlık Kurulu “399 nolu” karar tutanağı. 2013. http://www.tuk.saglik.gov.tr/pdfdosyalar/kararlar/karar_399. pdf Alınma tarihi: 1 Ağustos 2014.

2. Kapıcıoğlu MiS. Yeni YÖK Yasa Taslağı'nda Tıpta Uzmanlık Eğitimi Çalıştayı. 28 Ocak 2013, İstanbul. http://medeniyet. edu.tr/content/userfiles/safa_kapicioglu_sunusu.pdf. Alınma tarihi: 10 Ağustos 2014.

3. Tıpta ve Diş Hekimliğinde Uzmanlık Eğitimi Yönetmeliği. 26 Nisan 2014 tarihli 28983 sayılı resmi gazete. http://www.tuk. saglik.gov.tr/tuey-2014.pdf Alınma tarihi: 1 Ağustos 2014.

4. Gönen E. 2012-2013 TOTBID-TOTEK Uzmanlık Eğitimi Geliş̧im Sınavı raporu (UEGS). 2013. İçinde: TOTEK ALTINCI DÖNEM 2011-2013. Ankara: Hermes Matbaacılık; 2013. s.36. http://www.totbid.org.tr/upload/files/UEGS\%202013\%20 rapor.pdf

5. Tıpta Uzmanlık Kurulu. Uzmanlık Eğitimi Çekirdek Müfredatları. http://www.tuk.saglik.gov.tr/mufredatlar.html Alınma tarihi: 1 Ağustos 2014.

6. Tıpta ve diş hekimliğinde uzmanlık dallarının çekirdek müfredat ve standartları. Versiyon 2.0 Taslak Dokümanları; 2013. http://www.tuk.saglik.gov.tr/muf2/index.html Alınma tarihi: 1 Ağustos 2014.

7. Tıpta Uzmanlık Kurulu. 23.06.2010 tarih ve 82 sayılı Karar. http://www.tuk.saglik.gov.tr/rotasyonlar.pdf Alınma tarihi: 1 Ağustos 2014.

8. Tıpta Uzmanlık Kurulu "479 nolu” karar tutanağı. 2014. http://www.tuk.saglik.gov.tr/pdfdosyalar/kararlar/karar_479. pdf Alınma tarihi: 1 Ağustos 2014.

9. Tıp Dekanları Konseyi Kuruluş ve Çalışma Esasları Yönergesi. 2012. http://www.tipdek.org/pdf/dekan_yonerge.pdf Alınma tarihi: 15 Ağustos 2014.

10. Tıpta Uzmanlık Kurulu. Mevzuat. http://www.tuk.saglik.gov. tr/mevzuat.html Alınma tarihi: 1 Ağustos 2014.

11. Tıpta Uzmanlık Kurulu “488 nolu” karar tutanağı. 2014. http://www.tuk.saglik.gov.tr/pdfdosyalar/kararlar/karar_488. pdf Alınma tarihi: 25 Ağustos 2014.

12. Türk Anesteziyoloji ve Reanimasyon Derneği başvurusu (Anesteziyoloji ve Reanimasyon Uzmanlık Eğitimi Süresinin 5 yıla çıkarılması hakkında). http://www.tuk.saglik.gov. tr/dokumanlar/anestezi_5yil/index.html Alınma tarihi: 25 Ağustos 2014.
13. Okur H. Sağlık Sisteminin Yeniden Yapılanması ile Tıpta Uzmanlık Eğitiminde Kurumlararası İşbirliği. İstanbul Medeniyet Üniversitesi. http://www.tipdek.org/pdf/ dicleuniv/sagliksistemininyenidenyapilanmasi.pdf Alınma tarihi: 23 Ağustos 2014.

14. Sosyal Güvenlik Kurumu Sağlık Uygulama Tebliği. Resmi Gazete: 24.03.2013 - 28597. http://www.ttb.org.tr/ mevzuat/index.php?option=com_content\&view=article\&id= 953:teblig\& Alınma tarihi: 21 Ağustos 2014.

15. Türkiye Sağlık Bilgi Sistemi Eylem Planı. S.B. Bilgi İşlem Daire Başkanlığı. 2014. http://sbu.saglik.gov.tr/Ekutuphane/ kitaplar/biyoistatistik\%2816\%29.pdf Alınma tarihi: 21 Ağustos 2014.

16. Ateş M. Birinci basamak sağlık hizmetleri. İçinde: Ateş $M$, editör. Sağlık Hizmetleri Yönetimi. I. Bölüm. İstanbul: Beta, Basım Yayım Dağıtım A.Ş.; 2011. s.1-38

17. TUKMOS Ortopedi ve Travmatoloji Uzmanlığı Müfredat ve Standart Belirleme Komisyonu. Ortopedi ve Travmatoloji Uzmanlık Eğitimi Müfredatı. 2011. v.1.0. http://www.tuk. saglik.gov.tr/muf1/index.html ve http://www.tuk.saglik.gov. tr/muf1/71_ortopedi_v.1.0.pdf Alınma tarihi: 1 Ağustos 2014.

18. Şenköylü A. Asistan karnesinde yapılan güncellemeler. İçinde: TOTEK ALTINCI DÖNEM 2011-2013. Ankara: Hermes Matbaacılık; 2013. s.88-96.

19. Kurumsal Eğitim Yönetimi ve Planlama Sistemi."KEYPS”. http://keyps.org/ Alınma tarihi: 21 Ağustos 2014.

20. İstanbul Medeniyet Üniversitesi. Yeni YÖK Yasa Taslağı'nda Tıpta Uzmanlık Eğitimi Çalıştayı. http://medeniyet.edu.tr/ Guncel_Haberler_yeni_yok_yasa_taslaginda_tipta_uzmanlik_ egitimi_calistayi_gerceklestirildi.html Alınma tarihi: 22 Ağustos 2014.

21. Hoşoğlu S. Uzmanlıkta tez gerekli mi? Uzmanlık/doktora bütünleşik eğitimi olabilir mi? http://www.tipdek.org/pdf/ dicleuniv/uzmanliktatezgereklimi.pdf Alınma tarihi: 21 Ağustos 2014.

22. Acemoğlu H. Beceri eğitimleri: illeri teknoloji ürünü maket, manken ve sanal programlar. http://www.tipdek.org/pdf/ dicleuniv/beceriegitim.pdf Alınma tarihi: 21 Ağustos 2014.

23. EFORT, European Educational Platform Draft Curriculum. J2014. https://www.efort.org/london2014/

24. Türkiye Sağlık Enstitüleri Başkanlığı Kurulması ile Bazı Kanun ve Kanun Hükmünde Kararnamelerde Değişiklik Yapılmasına Dair Kanun Tasarısı. http://www.tbmm.gov.tr/develop/owa/ tasari_teklif_sd.onerge_bilgileri?kanunlar_sira_no= 157018 ve http://www.tbmm.gov.tr/sirasayi/donem24/yil01/ss615. pdf Alınma tarihi: 26 Ağustos 2014. 